\title{
Transcriptomic Study of B-cell associated X (BAX) and B-cell lymphoma (BCL2) Protein in Breast Cancer Ayshan Rafat Yassin (MSc) ${ }^{1}$, Ashti Mohammad Amin Said (MSc) ${ }^{2}$ and Yasin Kareem Amin $(\mathrm{PhD})^{3}$ Abstract
}

Background: Cancer is one of the major human problems and breast cancer is a significant health problem. In spite of the developed treatment methods, breast cancer cannot be treated very effectively. Therefore, the identification of novel genes that will have played a role in the treatment and diagnosis of breast cancer and the high interest of B-cell lymphoma (BCL2) family proteins are critical regulators of apoptosis).

Objective: The current study aimed to investigate the relationship between the levels of BCL2, BAX, and B-cell integrate medium (BIM) proteins which the prognosis and apoptosis processes of the breast cell line.

Patients and Methods: Collected tissue samples from normal and cancer tissue type, RNA isolated from the cell, then quantitation done, cDNA synthesized, cDNA quantitation and Real-time PCR was performed to see the level between two kinds of genes.

Results: BCL2 protein level was significantly lessened in regulator molecule tissues of a cell line with breast cancer. In contrast to Bax protein, no significant difference was detected in the BIM expression level. Our result also showed that low BCL2 expression level is associated with significant clinical characteristics of the patient such as tumor grade, stage and breast cancer type.

Conclusion: Findings of our study showed that BCL2 has a role in breast cancer formation and might be a novel biomarker for the diagnosis and treatment of breast cancer.

Keywords: Apoptosis, BCL2, Breast Cancer, gene expression, BAX, BIM.

Corresponding Author: ishanku@yahoo.com

Received: $9^{\text {th }}$ January 2019

Accepted: $17^{\text {th }}$ February 2019

${ }^{1,2,3}$ Medical Research Center -Hawler Medical University-Erbil- Iraq

\section{Introduction}

Breast cancer is a major health problem in all countries and predominantly affects women population.1It is the most common type of cancer in women and responsible for the most cancer-related death among women population[2].In the United States, it is estimated that 255,180 new cases of breast cancer and 41,070 breast cancer-related deaths will occur3. Also, according to 2014 cancer statistics in Turkey, breast cancer (24.9\%) is the most common cancer of women in all age groups[1]. 
Apoptotic regulatory molecules triggered by p53, such as Bax, FAS/pol, and BCL2, provide the tumor suppressor property of p53.4 Myc and p53 direct cells to apoptosis through Max pathway and DNA damage, respectively[5].Also, $\mathrm{Bcl} 2$ proto-oncogene maintains cell viability by inhibiting apoptosis. Presence of Bcl-2 is essential for maintaining cell viability. While some of the members of the BCL family proteins such as Bcl-2, Bcl-XL, Bcl-W and Mcl-1interferes with the induction of apoptosis and some of them such as Bax, Bak, Bad, Bik, Bid and BclxS induce apoptosis [6].

In many types of cancer, tumor cells gain resistance to apoptotic death by inducing the expression of anti-apoptotic $\mathrm{Bcl}-2$ proteins and inhibiting the expression of pro-apoptotic proteins such as Bax, leading to disruption of the p53 mechanism. 7 Bax proteins are one of the key molecules that lead to multidrug resistance to the cell, especially in cancer patients. 8 The excess level of Bcl-2 inhibits cell death whereas low levels of $\mathrm{Bcl}-2$ increase the susceptibility of the cell to various toxins. 9 The ratio of $\mathrm{Bax}$ to $\mathrm{Bcl}-2$ is an essential indicator of the susceptibility of the cell to apoptosis 10. Therefore, the Bax / Bcl-2 ratio can be used as criteria in assessing the course of the disease in various carcinomas[11].Caspase-3 regulates the Bax / $\mathrm{Bcl}-2$ ratio and plays a crucial role in apoptosis. Bcl-2 is also a death mediator for caspases and accelerates cell death by inactivating the function of $\mathrm{Bcl}-2$ against apoptosis[12].
The $\mathrm{Bcl} 2$ is a major protein which plays an important role to regulate cell death. These contact between two proteins can form a complex between four protein each other called homologous regions termed $\mathrm{Bcl}$ homology $(\mathrm{BH})$ domains; It has been found that $\mathrm{Bcl} 2$ play an essential role in cancer cell for treatment and radiation therapy and chemotherapy. Bcl2 can promote the expansion level tumor cell by preventing normal cell turnover caused by physiotherapy cell death mechanisms[13,14].Bcl2 in different human cancer cell cause to a high level in expression range of $\mathrm{Bcl} 2$ effect on the powerful of cancers to a wide range of chemotherapeutic drugs and $\gamma$-irradiation which active of death cell in a tumor cell by inhibition of $\mathrm{Bcl} 2[15]$.

B-cell CLL/lymphoma 2 (BCL2) encodes an integral outer mitochondrial membrane protein that blocks the apoptotic death of some cells such as lymphocytes, and it is located on chromosome 18q21.3 and has six exons[16]. The BCL2 protein, encoded by the BCL2 gene, is the founding member of the BCL2 family of regulatory proteins that regulate cell death (apoptosis), by either inducing (proapoptotic) or inhibiting (antiapoptotic) apoptosis. BCL2 is the essential antiapoptotic protein, and thus its gene is classified as an oncogene in general[17].

Although BCL2 was usually present in human follicular B cell lymphoma, carry genetic information of translocation, 18 and the scientist explain that this protein has an essential role in cancer cell line especially in 
leukemia, cancer, prostate cancer, gastric cancer, and pancreatic cancer, among others[19].Callagy [ 20] reported that BCL2 is an independent predictor of favorable outcomes in breast cancer, particularly in the first five years after diagnosis. Berardo[21] Reported that high BCL2 expression is associated with some good prognostic factors and independently with a better clinical outcome for patients of lymph node-positive breast carcinoma[22].

Bcl-2 family proteins are classified into three subfamilies. These subfamilies are apoptosis inhibitors (anti-apoptotic), apoptosis promoters (pro-apoptotic) multidomain proteins and BH3-only proteins[23].

The aim and scope of this study were the BCL2, and BAX is high interest in cancer treatment, even though the biological significance remains still under scientific investigation with major key questions yet to be elucidated.

\section{Patients and Methods}

\section{Participants}

Collection of the sample from normal and cancer tissue type in cell line RNA isolation from the cell, RNA quantitation, cDNA synthesis, cDNA quantitation, and RealTime- PCR analysis.

\section{RNA isolation from cell line}

After cells reach $80-90 \%$ density, they are removed for RNA isolation under appropriate conditions. RNA was extracted from cell culture using High Pure RNA Isolation (Roche, Mannheim, Germany) kit. The RNA isolation protocol is as follows; The cells with appropriate density are removed with Trypsin, and DMEM containing FCS is added to stop the effect of trypsin Cells are centrifuged at $3500 \mathrm{rpm}$ for $5 \mathrm{~min}$. The supernatant is removed without touching the pellet. The remaining pellet is resuspended in $200 \mu \mathrm{l} \mathrm{PBS}$. Add $400 \mu \mathrm{l}$ of Lysis Buffer to this mixture and vortex for 15 seconds. The whole mixture is transferred to filter tubes, centrifuged for 30 seconds at $9200 \mathrm{rpm}$. The lower part is discarded. Add $100 \mu \mathrm{l}(10 \mu \mathrm{l}$ DNAse and $90 \mu \mathrm{l}$ DNAse incubation buffer) to the filtered tubes and wait at room temperature for 45 minutes. Add $500 \mu \mathrm{l}$ Wash Buffer I and centrifuge at $9200 \mathrm{rpm}$ for 30 seconds. The lower part is discarded. Then add $500 \mu \mathrm{l}$ Wash Buffer II and centrifuge at $9200 \mathrm{rpm}$ for 30 seconds. The bottom tube is replaced with the new one. Add $200 \mu \mathrm{l}$ of Wash Buffer II and centrifuge for 2 minutes at $11800 \mathrm{rpm}$. The lower tube is discarded, and a new tube is inserted. After this, add $50 \mu \mathrm{l}$ of Elution Buffer and wait for 1 minute at room temperature. Centrifuge at $9200 \mathrm{rpm}$ for 1 minute. The filtered tube is discarded. Measurements were made on the NanoDrop 1000 to determine the amount of RNA. RNAs are stored at $-80{ }^{\circ} \mathrm{C}$ until the working period.

\section{RNA Quantitation}

Determination of quantity and quality of obtained RNA samples were done by detecting A260/A280 ratio using Nanodrop spectrophotometer. For PCR reactions, RNA was diluted according to their density.

cDNA components and their amounts Single-stranded cDNA synthesis from RNA- 
isolated samples and tissue RNAs was performed with Maxima $\mathrm{H}$ Minus First Strand cDNA Synthesis Kit \# K1652 (Thermo Scientific). From the cell culture samples, cDNA synthesis was performed by adding RNA at a final concentration of $2 \mu \mathrm{g} /$ $\mu \mathrm{l}$ RNA and tissue RNA at a final concentration of $1 \mu \mathrm{g} / \mu \mathrm{l}$ RNA.

\section{Real-Time PCR (qPCR) Analyzes}

QPCR was performed to determine expression levels of target genes more effectively in tissues and cell lines. For this experiment, a Rotor-Gene Q (QIAGEN,) Real-Time PCR instrument was used. qPCR experiments were performed in the direction of the manufacturer's firm using Maxima SYBR Green / ROX qPCR Master Mix (\# K0251). For this study, appropriate synthetic primers were designed for exon regions of $\mathrm{Bcl} 2$ and Bax and bim genes by using the NCBI/Primer Blast database. Forward and reverse BCL2 gene are: 5GTTGCATCAGCTGTCCTCCT -3 , 3 AAAAAGGGGTTGGGGTAGG5. Forward and reverse $\mathrm{Bax}$ gene are 5ACCAGACCTACTCTTCCGCT-3, 3GGGAAGAGCCAAGTCAGAC-5. Forward and reverse Bim gene are: -5 ATCTGGTGAGCCAGGTAGGA -3 , 3GGGAAGAGCCAAGTCAGAC -5.

\section{Statistical analysis}

The evaluation was performed by using GraphPad Prism 7 for evaluation of the invasive ductal + lobular subtype.

\section{Results}

The characteristics of the cell line who diagnosed with breast cancer were listed in
Table (1). The mean age of the patients included in the study was $51.91 \pm 13.05$. Of these, $32.8 \%$ are under 45 years of age, $51.7 \%$ are between $45-65$ years of age, and $15.5 \%$ are over 65 years of age. According to breast cancer subtypes, $79.3 \%$ of these patients were invasive ductal carcinoma, 19\% were invasive lobular carcinoma, and $1.7 \%$ were the invasive ductal + lobular type.

Figure (1) illustrates the expression levels of $\mathrm{Bcl} 2$ protein was found to be significantly diminished in the tumoral tissues of breast cancer patients as compared to normal tissues $(\mathrm{p}=0.0078)$.

In Table (1) BCL2 expression levels of breast cancer patient were shown according to age $(<45,45-65,>65)$. BCL2 protein levels compared with the age distribution, it was found to be more prevalent in 65 year age tumor samples. Also, the expression level of bcl 2 protein was found to be higher in patients over 65 years of age than in any other age groups.

Moreover, the expression level of Bax protein was shown according to the invasive ductal and lobular subtypes of breast cancer. Particularly, expression levels of Bax protein were found to be significantly decreased in breast cancer patients with invasive ductal carcinoma. Also, Bax protein expression levels were also found to be diminished in invasive lobular carcinoma patients, yet this change was statistically insignificant $(p=0.0271)$ Figure (2). Statistical evaluation was performed for the invasive ductal + lobular subtype due to the presence of only one patient. 
According to the histopathological staging of the patients, $8.6 \%$ were stage $1,36.2 \%$ were stage 2 , and $34.5 \%$ were stage 3 . Also, the histopathologic stage of $20.7 \%$ of these patients is unknown. TNM is very important in the detection of breast cancer stages for the determination of appropriate diagnosis and treatment method. The frequency of patients was determined according to each parameter ( $\mathrm{T}, \mathrm{N}$, and $\mathrm{M})$ in the TNM classification. Detailed information about the patients is shown in Table (2).

Expression levels of Bax protein were found to be significantly diminished in the tumoral tissues of breast cancer patients as compared to normal tissues ( $\mathrm{p}=0.0078$ ) Figure(1).

There was no significant difference in BIM protein expression between normal and tumor tissues in breast cancer patients $(p>0.05)$ Figure(3). Expression levels of Bax were found to be significantly increased in the tumoral tissues of breast cancer patients with invasive ductal carcinoma $(\mathrm{p}=0.0001)$ Figure (5). However, in invasive lobular carcinoma, Bax protein was not detected in normal and tumorous breast tissues. Figure 4 show the expression levels of Bax protein according to different age groups.

Table (1): Clinical characteristics of the cell line included in the study.

\begin{tabular}{|c|c|c|c|c|}
\hline \multicolumn{3}{|c|}{ Demographic characteristics } & $\mathrm{n}=58$ & $\% \mathrm{n}$ \\
\hline \multicolumn{2}{|c|}{ Age } & $<4<5(38,47 \pm 4,40)$ & 19 & 32,8 \\
\hline & & $45-65(53,66 \pm 5,52)$ & 30 & 51,7 \\
\hline & & $>65(74,44 \pm 6,44)$ & 9 & 15,5 \\
\hline \multicolumn{2}{|c|}{ Diagnosis } & Invasive ductal & 46 & 79,3 \\
\hline & & Invasive lobular & 11 & 19,0 \\
\hline & & Invasive ductal + lobular & 1 & 1,7 \\
\hline \multicolumn{2}{|c|}{ Grade } & G1 & 5 & 8,6 \\
\hline & & $\mathrm{G} 2$ & 21 & 36,2 \\
\hline & & G3 & 20 & 34,5 \\
\hline & & Unknown* & 12 & 20,7 \\
\hline \multirow[t]{9}{*}{ TNM } & \multirow[t]{4}{*}{$\mathrm{T}$} & $\mathrm{T} 1$ & 11 & 19,0 \\
\hline & & $\mathrm{T} 2$ & 33 & 56,9 \\
\hline & & T3 & 12 & 20,7 \\
\hline & & $\mathrm{T} 4$ & 1 & 1,7 \\
\hline & \multirow[t]{4}{*}{$\mathrm{N}$} & N0 & 20 & 34,5 \\
\hline & & N1 & 13 & 22,4 \\
\hline & & $\mathrm{N} 2$ & 13 & 22,4 \\
\hline & & N3 & 11 & 19,0 \\
\hline & $\mathrm{M}$ & $\mathrm{Mx}$ & 57 & 100,0 \\
\hline
\end{tabular}

*T category describes the primary tumor site, $\mathrm{N}$ category describes the regional lymph node involvement, $\mathrm{M}$ category describes the presence or otherwise of distant metastatic spread 
Table (2): Representation of the Bax protein expression levels according to the patient characteristics.

\begin{tabular}{|c|c|c|c|c|c|}
\hline \multicolumn{2}{|c|}{ Characteristic } & & Bcl2-normal & Bcl2-tumor & $\mathrm{P}$ value \\
\hline \multirow[t]{3}{*}{ Age } & $<45$ & & $4,36 \pm 2,33$ & $3,73 \pm 1,82$ & 0,175 \\
\hline & $45-65$ & & $4,16 \pm 2,03$ & $3,96 \pm 2,12$ & 0,415 \\
\hline & $>65$ & & $5,4 \pm 2,06$ & $4 \pm 1$ & 0,062 \\
\hline \multirow[t]{3}{*}{ Diagnosis } & \multicolumn{2}{|c|}{ Invasive ductal } & $4,3 \pm 2,02$ & $3,69 \pm 1,54$ & 0,0271 \\
\hline & \multicolumn{2}{|c|}{ Invasive lobular } & $5 \pm 2,75$ & $4,72 \pm 2,8$ & 0,500 \\
\hline & \multicolumn{2}{|c|}{ Invasive ductal + lobular } & 4 & 4 & 1 \\
\hline \multirow[t]{3}{*}{ Grade } & G1 & & $4,6 \pm 2,4$ & $4 \pm 2,34$ & 0,5 \\
\hline & $\mathrm{G} 2$ & & $4,23 \pm 1,57$ & $3,19 \pm 1,12$ & 0,002 \\
\hline & G3 & & $4,3 \pm 2,4$ & $4,15 \pm 1,63$ & 0,769 \\
\hline \multirow[t]{9}{*}{ TNM } & $\mathrm{T}$ & $\mathrm{T} 1$ & $4,63 \pm 2,06$ & $2,72 \pm 1,55$ & 0,001 \\
\hline & & $\mathrm{T} 2$ & $4,51 \pm 2,16$ & $4,24 \pm 1,83$ & 0,403 \\
\hline & & $\mathrm{T} 3$ & $3,83 \pm 2,16$ & $3,75 \pm 1,65$ & 0,999 \\
\hline & & $\mathrm{T} 4$ & 3 & 3 & 1 \\
\hline & $\mathrm{N}$ & N0 & $4,4 \pm 1,87$ & $3,95 \pm 1,60$ & 0,300 \\
\hline & & $\mathrm{N} 1$ & $5,23 \pm 2,62$ & $4,3 \pm 2,59$ & 0,031 \\
\hline & & $\mathrm{N} 2$ & $4,23 \pm 2,04$ & $3,92 \pm 1,49$ & 0,562 \\
\hline & & N3 & $3,45 \pm 1,80$ & $2,9 \pm 1,13$ & 0,25 \\
\hline & M & Mx & $4,43 \pm 2,15$ & $3,89 \pm 1,87$ & 0,014 \\
\hline
\end{tabular}
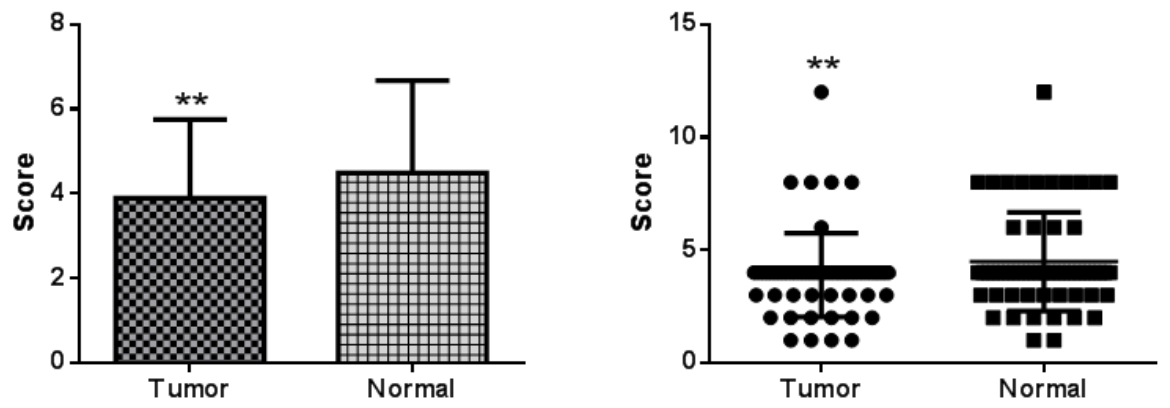

Figure (1): The expression level of Bcl2 protein in normal and tumor tissues of breast cancer patients $* * \mathrm{p}=0.0078$.

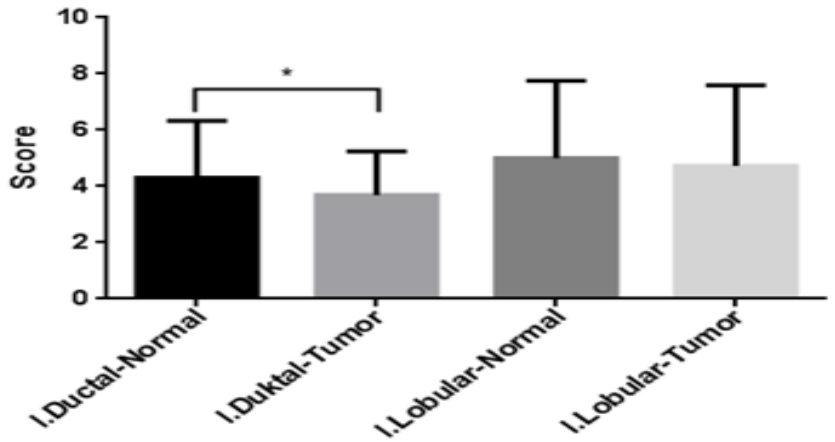

Figure(2): Bcl2 protein expression levels according to breast cancer diagnosis, ${ }^{*} \mathrm{p}=0.0271$. 

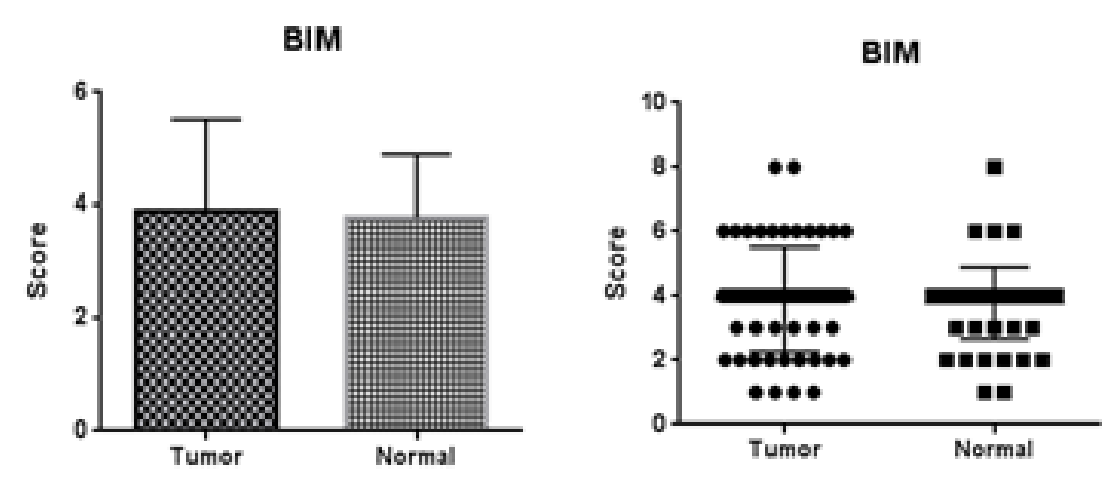

Figure (3): Expression levels of BIM protein in normal and tumor tissues of breast cancer patients.
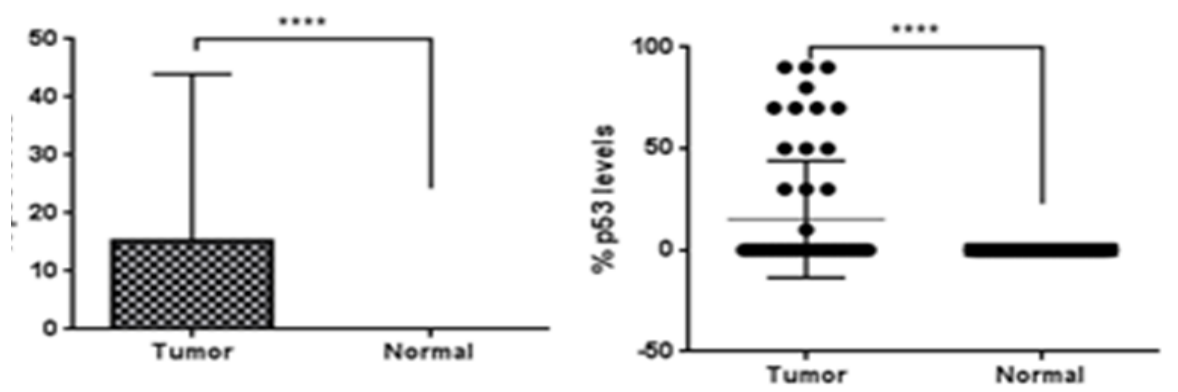

Figure (4): Expression levels of Bax protein in normal and tumor tissues of breast.

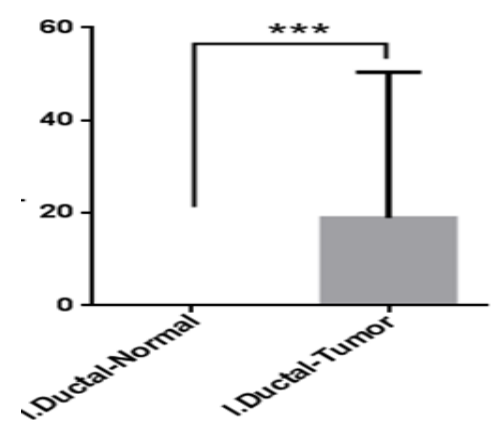

Figure (5): Expression levels of Bax protein in invasive ductal carcinoma breast cancer subtype. **** $\mathbf{p}=\mathbf{0 . 0 0 0 1}$.

\section{Discussion}

Breast cancer is the cause of death in female all over the world, with about 1.3 million cases affected yearly and approximately 500,000 deaths[21].

For therapeutic and prognostic reasons, breast cancer of female is treated on the expression of the estrogen receptor (ER), progesterone receptor (PR), and the epidermal growth factor receptor (EGFR) 
subtype HER2.25Another more differentiated methodology used in the characterization of breast cancers is tumor grading.26 For this reason, oncologists classify breast cancer subtypes as HER2-overexpressing breast cancer causing to the luminal B (higher grade, ER-positive), luminal A (low grade, ER-positive), TNBC (triple-negative breast cancers lacking ER, PR, HER2), normal breast-like tumors, and claudin-low (triplenegative invasive ductal carcinomas with a low expression of cell adhesion molecules). ER-positive breast cancers, which represents approximately $70 \%$ of all breast cancers 27 , are estrogen dependent and thus responds to treatment with anti-estrogens, such as ER antagonists 4-hydroxytamoxifen and raloxifene 28. ER-, PR-, and HER2-negative (triple negative) breast cancers still cannot be effectively treated. Therefore, to develop effective treatment approaches specific to breast cancer subtypes, expression profiles need to be studied in detail[29].

In normal cells, apoptosis is considered as a natural defensive mechanism against cancer development and the resistance of cancer cells to apoptosis is listed as one of the most important hallmarks of cancer.30 Thus, the basis of the currently used cancer treatment methods is to trigger apoptosis in cancer cells. At the molecular level. Cancer is caused by a series of mutations and or disorders that occur in genes that play a role in the execution and regulation of vital cellular activities such as cell proliferation, death, and differentiation[31].The genes contain in the formation and progression of cancers are generally known as tumor suppressor genes and oncogenes[32].

In this study, the range of expression of the $\mathrm{Bcl} 2$ gene was determined in a total number of 58 patients who diagnosed with breast cancer Table(1). The expression level of bcl2 average in 65 years has increase than other age groups. The expression level of Bax can be increased in ductal tissue if when compared with the normal tissue depend on a grade of the tumor. The expression level of BIM was the same in normal and tumor cells that it means there is no any significant difference to Figure [3].

\section{Acknowledgments}

This study has been supported by the Medical Research Center/Hawler Medical University, Kurdistan Iraq.

\section{References}

[1]Unal M. Meme kanserinde Klinik bulgular ve evreleme. İçinde: Meme kanseri. Stanbul Üniversitesi, Onkoloji Enstitüsü Yayınlar1 3 1997:129-130.

[2]Baldassarre G, Belletti B. Molecular biology of breast tumors and prognosis. F1000Research. 2016;5.

[3]Tarver T. Cancer facts \& figures 2012. American cancer society (ACS) Atlanta, GA: American Cancer Society, 2012. 66 p., pdf. Available from.

[4]Di Lonardo A, Nasi S, Pulciani S. Cancer: we should not forget the past. Journal of Cancer. 2015;6(1):29.

[5] Hajdu SI. A note from history: landmarks in history of cancer, part 1. Cancer. 2011 Mar 1;117(5):1097-102. 
[6] Balmain A. Cancer genetics: from Boveri and Mendel to microarrays. Nature reviews cancer. 2001 Oct;1(1):77.

[7] Danial NN, Korsmeyer SJ. Cell death: critical control points. Cell. 2004 Jan 23;116(2):205-19.

[8]Kidd VJ. Proteolytic activities that mediate apoptosis. Annual review of physiology. 1998 Mar;60(1):533-73.

[9] Tzifi F, Economopoulou C, Gourgiotis D, Ardavanis A, Papageorgiou S, Scorilas A. The role of BCL2 family of apoptosis regulator proteins in acute and chronic leukemias. Advances in hematology. 2012;2012.Article ID 524308, 15 pages doi:10.1155/2012/524308.

[10]Martin B, Paesmans M, Berghmans T, Branle F, Ghisdal L, Mascaux C, Meert AP, Steels E, Vallot F, Verdebout JM, Lafitte JJ. Role of Bcl-2 as a prognostic factor for survival in lung cancer: a systematic review of the literature with meta-analysis. British journal of cancer. 2003 Jul 1;89(1):55.

[11] Li R, Moudgil T, Ross HJ, Hu HM. Apoptosis of non-small-cell lung cancer cell lines after paclitaxel treatment involves the BH3-only proapoptotic protein Bim. Cell death and differentiation. 2005 Jan;12(3):292.

[12] Li R, Ding C, Zhang J, Xie M, Park D, Ding Y, Chen G, Zhang G, Gilbert-Ross M, Zhou W, Marcus A. Modulation of Bax and mTOR for cancer therapeutics. Cancer research. 2017 Jan 1:canres-2356.

[13] Siddiqui WA, Ahad A, Ahsan H. The mystery of BCL2 family: Bcl-2 proteins and apoptosis: an update. Archives of toxicology. 2015 Mar 1;89(3):289-317.

[14]Tsujimoto Y, Finger LR, Yunis J, Nowell PC, Croce CM. Cloning of the chromosome breakpoint of neoplastic B cells with the $\mathrm{t}(14 ; 18)$ chromosome translocation. Science. 1984 Nov 30;226(4678):1097-9.

[15]Tzifi F, Economopoulou C, Gourgiotis D, Ardavanis A, Papageorgiou S, Scorilas A. The role of BCL2 family of apoptosis regulator proteins in acute and chronic leukemias. Advances in hematology. 2012;2012:524308.

[16]Cui J, Placzek W. Post-transcriptional regulation of anti-apoptotic BCL2 family members. International journal of molecular sciences. 2018 Jan 20;19(1):308.

[17] Del Principe MI, Dal Bo M, Bittolo T, Buccisano F, Rossi FM, Zucchetto A, Rossi D, Bomben R, Maurillo L, Cefalo M, De Santis G. Clinical significance of bax/bcl-2 ratio in chronic lymphocytic leukemia. Haematologica. 2016 Jan 1;101(1):77-85.

[18] Akiyama T, Dass CR, Choong PF. Bimtargeted cancer therapy: a link between drug action and underlying molecular changes. Molecular cancer therapeutics. 2009 Dec 1;8(12):3173-80.

[19] Wen YY, Yang ZQ, Song M, Li BL, Zhu JJ, Wang EH. SIAH1 induced apoptosis by activation of the JNK pathway and inhibited invasion by inactivation of the ERK pathway in breast cancer cells. Cancer science. 2010 Jan;101(1):73-9.

[20] Salakou S, Kardamakis D, Tsamandas AC, Zolota V, Apostolakis E, Tzelepi V, 
Papathanasopoulos P, Bonikos DS, Papapetropoulos T, Petsas T, Dougenis D. Increased $\mathrm{Bax} / \mathrm{Bcl}-2$ ratio up-regulates caspase- 3 and increases apoptosis in the thymus of patients with myasthenia gravis. In vivo. 2007 Jan 1;21(1):123-32.

[21] Borden KL. RING domains: master builders of molecular scaffolds?. Journal of molecular biology. 2000 Feb 4;295(5):110312.

[22]Habelhah H, Frew IJ, Laine A, Janes PW, Relaix F, Sassoon D, Bowtell DD, Ronai ZE. Stress-induced decrease in TRAF2 stability is mediated by Siah2. The EMBO journal. 2002 Nov 1;21(21):5756-65. [23] Siegel RL, Miller KD, Jemal A. Cancer statistics, 2016. CA Cancer J Clin. 2016 JanFeb;66(1):7-30. doi: 10.3322/caac.21332. Epub 2016 Jan 7. 2016.

[24]Kushi LH, Kwan ML, Lee MM, Ambrosone CB. Lifestyle factors and survival in women with breast cancer. The Journal of nutrition. 2007 Jan 1;137(1):236S$42 \mathrm{~S}$.

[25]Lotfi MH, Shobairi SC. Breast cancer risk factors in an urban area of Yazd CityIran, 2006. Acta Medica Iranica. 2008;46(3):253-7.

[26]Casciato DA, Territo MC, editors. Manual of clinical oncology. Lippincott Williams \& Wilkins; 2009.

[27]Couto E, Hemminki K. Estimates of heritable and environmental components of familial breast cancer using family history information. British journal of cancer. 2007 Jun;96(11):1740.
[28]Largent JA, Capanu M, Bernstein L, Langholz B, Mellemkjær L, Malone KE, Begg CB, Haile RW, Lynch CF, AntonCulver H, Wolitzer A. Reproductive history and risk of second primary breast cancer: the WECARE study. Cancer Epidemiology and Prevention Biomarkers. 2007 May 1;16(5):906-11.

[29] Worsham MJ, Raju U, Lu M, Kapke A, Cheng J, Wolman SR. Multiplicity of benign breast lesions is a risk factor for progression to breast cancer. Clinical Cancer Research. 2007 Sep 15;13(18):5474-9.

[30]Wen YY, Yang ZQ, Song M, Li BL, Yao XH, Chen XL, Zhao J, Lu YY, Zhu JJ, Wang EH. The expression of SIAH1 is downregulated and associated with Bim and apoptosis in human breast cancer tissues and cells. Molecular Carcinogenesis: Published in cooperation with the University of Texas MD Anderson Cancer Center. 2010 May;49(5):440-9.

[31]Hu G, Fearon ER. Siah-1 N-terminal RING domain is required for proteolysis function, and C-terminal sequences regulate oligomerization and binding to target proteins. Molecular and cellular biology. 1999 Jan 1;19(1):724-32.

[32] Eliyatkın N, Yalçın E, Zengel B, Aktaş S, Vardar E. Meme Karsinomunda Moleküler Sınıflama: Gelenekselden Yeni Döneme Yolculuk. Meme Sagligi Dergisi/Journal of Breast Health. 2015 Apr $1 ; 11(2)$. 